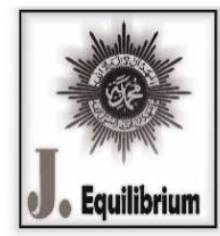

Equilibrium : Jurnal Pendidikan

Vol. VIII. Issu 2. Juni-Desember 2020

Prodi Pendidikan Sosiologi

Sosiologi

http://journal.unismuh.ac.id/index.php/equilibrium

\title{
Persepsi Siswa Tentang Keberagaman Agama di Kota Tanjungpinang
}

\author{
Desrian Effendi ${ }^{1}$, Endri Bagus Prastiyo², Vidcy Trimadanu ${ }^{3}$ \\ ${ }^{1}$ Sekolah Tinggi IImu Sosial dan IImu Politik Raja Haji Tanjungpinang. \\ desrianeffendi03@gmail.com \\ ${ }^{2}$ Sekolah Tinggi Ilmu Sosial dan Ilmu Politik Raja Haji Tanjungpinang. \\ endribagus@stisipolrajahaji.ac.id \\ ${ }^{3}$ Sekolah Tinggi Ilmu Sosial dan Ilmu Politik Raja Haji Tanjungpinang. \\ trimadanuvidcy@gmail.com
}

\begin{abstract}
This study is aimed at knowing students' perceptions of religious diversity in the city of Tanjungpinang City. Religious diversity is interesting to see in the city of Tanjungpinang because this social fact can be an example for other cities in Indonesia and why students are the subject of research because schools are objects in research and see that the student's place, namely school, is the basis that school is a place or place. where students from different religious backgrounds gather where there will be interactions, actions, and social realities that occur in the school environment. The methodology in this research is descriptive with a quantitative approach. The location of this research is SMA, SMK, MA in Tanjungpinang City. The focus of this research is religious diversity in the city of Tanjungpinang. Data collection techniques with questionnaires and documentation. Perceptions that arise in students do not just happen, but with interactions, actions, and seeing social realities in the school and home environment, from the results of the questionnaire data, researchers see that the perceptions that arise in students are the perceptions of students with several things, namely the statement of a leader who religious minorities become leaders, the existence and freedom of activities of religious organizations that are still running, activities of mutual empathy and mutual assistance to each other even though different religions are being hit by the disaster from the results that almost all of them above 90\% agree Suggestions in this study are that students are expected to maintain this diversity with positive activities and continue to interact with others regardless of ethnicity, religion, and race so that it will create a positive environment that creates positive perceptions.
\end{abstract}

Keywords : Perception; Students; Religious Diversity

Abstrak. Penelitian ini ditujukan untuk mengetahuai persepsi siswa tentang keberagaman agama di kota Kota Tanjungpinang. Keberagaman agama menarik untuk dilihat dikota Tanjungpinang karena fakta sosial ini bisa menjadi contoh bagi kota-kota lainnya yang ada di Indonesia dan mengapa siswa menjadi subjek penelitian karena sekolah menjadi objek dalam penelitian dan melihat bahwa tempat siswa yaitu sekolah menjadi dasar bahwa sekolah sebagai wadah atau tempat dimana berkumpulnya siswa yang berlatangbelakang agama yang berbeda dimana disana akan terdapat interaksi, tindakan, dan realitas sosial yang terjadi dalam lingkungan sekolah. Metodologi dalam penelitian ini bersifat deskriptif dengan pendekatan kuantitatif. Lokasi penelitian ini yaitu SMA,SMK,MA di Kota Tanjungpinang. Fokus penelitian ini yaitu keberagaman agama di kota Tanjungpinang. Teknik pengumpulan data dengan kuesioner dan dokumentasi. Persepsi yang timbul dalam diri siswa tidak terjadi begitu saja namun dengan adanya interaksi, tindakan, dan melihat realitas sosial di lingkungan sekolah dan rumahnya, dari hasil data kuesioner peneliti melihat bahwa persepsi yang timbul disiswa yaitu persepsi siwa dengan beberapa hal yaitu dengan pernyataan adanya pemimpin yang beragama minoritas menjadi pemimpin, terdapatnya dan kebebasan kegiatan organisasi keagamaan yang masih berjalan, kegiatan saling empati dan saling membantu satu sama lainya meski berbeda agama yang sedang terkena musibah dari hasil bahwa hamper keseluruhan diatas $90 \%$ setuju.

Kata Kunci : Persepsi; Siswa; Keberagaman Agama 


\section{PENDAHULUAN}

Keberagaman atau diferensiasi sosial yang ada di Kota Tanjungpinang adalah diferensiasi sosiokultural yaitu diferensiasi agama. Deferensiasi agama adalah perbedaan individu dalam memeluk atau menganut sebuah agama yang dimana pembedaan ini tidak memiliki tingkatan artinya pembedaan secara horizontal. Siswa merupakan bagian dari masyarakat yang di mana jumlah mereka dalam segi usia mendominasi lapisan masyarakat pada saat ini, Integrasi ketahanan negara kita juga berada di tangan mereka. Sekolah merupakan tempat berkumpulnya Siswa yang berlatar belakang berbeda-beda antara satu dengan lainnya, baik dari segi keadaan keluarga, ekonomi, adat istiadat, agama maupun dari segi Sosiologi yaitu Persepsi, bakat dan minatnya. Maka akan memunculkan persepsi yang berbedabeda antara siswa melihat keberagaman yang di terima. Dilihat dari segi Sosiologi, menurut penulis perbedaan persepsi pada siswa merupakan hal yang menarik, karena setiap orang memiliki persepsi yang berbeda-beda terhadap objek yang sama. Hal ini dikarenakan berbagai macam faktor yang mempengaruhinya.

Persepsi merupakan proses awal dari interaksi manusia dengan lingkungan sekitarnya, persepsi merupakan proses subjekif pengolahan bagaimana manusia dapat menilai suatu objek. Dalam arti luasnya persepsi merupakan pandangan atau pengertian bagaimana seseorang memandang atau mengartikan sesuatu. Persepsi merupakan hal yang penting karena pandangan seseorang berprilaku terhadapt suatu objek atau individu lain tidaklah sama. Persepsi siswa terhadap keberagaman agama ini perlu diketahui dengan pertimbangan bahwa siswa adalah bagian dari masyarakat yang dari segi usia sudah bisa berfikir atau berpandangan secara baik dan rasional dengan melihat realitas sosial yang terjadi di lingkungannya sehingga demikian dapat dilakukan beberapa penyesuaian yang tepat agar keberagaman ini dapat terus terjaga dari generasi ke generasi.

Keresahan peneliti melihat keadaan ini bukan tanpa alasan, karena saat ini peneliti melihat bahawa kondisi-kondisi seperti ini jika tidak terus dijaga akan sangat mengancam Keberagaman. Hal ini dapat memicu ketidakharmonisan dalam kehidupan masyarakat kota Tanjungpinang yang sejak dulu sangat menjunjung tinggi nilai pluralitas. Peneliti juga menyikapi beberapa kejadian- kejadian yang terjadi dimasyarakat maupun di kalangan siswa di kota Tanjungpinang yang sudah mulai berkurang nilai pluralitasnya, hal ini terlihat dari adanya kelompok-kelompok yang melarang ucapan selamat hari besar agama lain, adanya larangan mengunjungi tempat-tempat ibadah agama lain, bahkan juga pernah terjadi penolakan rumah ibadah agama lain dari agama mayoritas dan sistem pembelajaran di sekolah yang dimana pada saat mata pelajaran Agama sebagaiman misal pada saat mata pelajaran agama islam mereka siswa yang bukan beragama islam akan disuruh keluar dari kelas dan jam mata pelajaran tersebut dengan menggantikannya dengan kegaiatan lainnya, hal ini menurut peneliti jika tidak bisa dipahami dengan baik oleh siswa bisa menjadi sebuah pandangan yang buruk bagi agama tertentu dengan pemisahan yang begitu terasa sehingga minoritas akan selalu merasa di kucilkan di lingkungan mayoritas walaupun keadaan seperti ini sudah dianggap biasa di lingkungan pendidikan.

Hal ini juga dapat kita lihat dalam penelitian Jurnal Studi Al-Qur'an Vol. 14, No. 1, Tahun.2018 Membangun Tradisi Berfikir Qur'an yang berjudul Toleransi Antar Umat Beragama Perspektif KH. Ali Mustafa Yaqub, dalam bagian toleransi terhadap sesame agama toleransi beragama adalah toleransi yang mencakup masalah-masalah keyakinan pada diri manusia yang berhubungan dengan akidah atau yang berhubungan dengan ke-Tuhanan yang diyakininya. Seseorang harus diberikan kebebasan untuk menyakini dan memeluk agama (mempunyai akidah) masing masing yang dipilih serta memberikan penghormatan atas pelaksanaan ajaran-ajaran yang dianut atau yang diyakininya. Artinya kita sebagai masyarakat yang beragama yang beragam harus saling menghormati akidah dan kegiatan ketuhaan yang dilakukan oleh sesama masyarakat baik itu seagama dan yang berbeda agama.

Kota Tanjungpinang merupakan ibukota Provinsi Kepulauan Riau yang memiliki keberagaman agama didalamnya, Keberagaman agama yang ada di Kota Tanjungpinang sudah ada semenjak kota ini mulai berkembang. Kota Tanjungpinang sendiri memiliki mayoritas agama islam, dengan agama kedua 
yang terbanyak adalah agama budha yang didominasi oleh etnis Tionghua serta ada Protestan, Katolik, Hindu dan juga Lainnya. Dengan jumlah penduduk 220.812 jiwa yang ada di kota Tanjungpinang (BPS Kota Tanjungpinang 2020), jelas pasti ada berbagai keberagaman yang ada, Nilai-nilai agama yang di terima dan didapatkan oleh individu pasti terjadi di dalam kehidupan sehari-hari tidak terlepas bagi siswa yang hampir separuh harinya di habiskan di sekolah atau tempat dimana mereka mendapatkan pendidikan baru selanjutnya didapatkan di rumah, lingkungan bermain atau tempat tinggal, dan media sosial. Yang pada saat ini tidak bisa terlepas dari media sosial yang dapat membangun suatu pandangan bagi individu maupun kelompok.

Sekolah sendiri bisa kita lihat sebagai lembaga masyarakat yang banyak kita dapati dan tempat berkumpulnya siswa-siswa yang saling berhubungan dengan latar belakang yang berbeda baik itu suku, agama, dan ras. Hal-hal inilah yang menjadi menarik perhatian peneliti ingin melihat keberagaman agama di kota Tanjungpinang dengan sasaran lembaga sekolah dan siswa sebagai respondenya karena dengan kita bisa melihat miniature keberagaman agama yang terjadi di masyarakat umum bisa tercermin di lembaga sekolah tersebut, dengan melibatkan siswa menjadi sumber data yang didapatkan dalam penelitian ini bukan tanpa alasan karena melihat dari hasil penelitian dari Jurnal Aqidah-Ta.UIN Alauddin Makassar yang ditulis oleh Indah rahayu yang berjudul Persepsi Siswa Smp Unismuh Makassar Terhadap Toleransi Antarumat Beragama tahun 2018, bahwa terdapat faktor-faktor yang Memengaruhi Rendahnya Persepsi Siswa terhadap Toleransi antarumat Beragama dan Upaya Optimalisasi Rekonstruksi Persepsi Siswa terhadap Toleransi antarumat Beragama. Yang pertama yaitu kekeliruan Pendidikan Menyikapi Perbedaan yang dimana siswa biasa hanya mendapatkan bahan ajaran yang sudah terstruktur yang telah disampaikan disekolah cuman minim contoh secara konkrit dan hubungan yang berdekatan dengan kehidupan siswa sendiri hal inilah yang menjadi timbulnya persepsi masingmasing siswa dalam melihat pendidikan tersebut khususnya mengenai keberagaman.

Jika hal ini dijadikan suatu problem dalam bertoleransi, maka akan memberi ruang untuk bersikap intoleran. Dan yang terakhir yaitu edia sosial Umat dewasa ini hidup di tengah-tengah zaman era digital seperti handphone, tablet, computer dan lain sebagainya. Kecanggian teknologi sedikit banyaknya akan memengaruhi cara pandang serta cara pikir seseorang yang sering terkontaminasi dengan benda-benda tesebut, baik yang diterima dampak positif maupun negatif. Media sosial merupakan salah satu faktor yang memengaruhi pemahaman dan sikap keberagamaan masyarakat sosial khususnya di kalangan terdidik (pelajar/peserta didik). Perangkat media sosial seperti facebook, whatsApp, youtube, instagram, dan lain sebagainya sering digunakan oleh masyarakat hari ini baik itu di kalangan anak remaja, dewasa bahkan sampai di kalangan orang tua. Dengan demikian atas dasar permasalahan dan uraian diatas peneliti melihat bahwa keberagaman agama yang terjadi di kota Tanjungpinang dengan data yang didapat dan dengan sasaran sekolah dan siswa menjadi sumber informasi/data yang didapatkan dalam penelitian ini dapat mendeskripsikan atas apa yang terjadi di lingkungan kita dengan berbagai permasalahan sosial, sehingga kedepannya kita dapat membaca hal ini dan peke terhadap keberagaman bahwa sesungguhnya kita hidup saling berdampingan dan senantiasa membutuhkan orang lain dalan menajalankan kehidupan bermasyarakat.

\section{METODE PENELITIAN}

Metodologi dalam penelitian ini bersifat deskriptif dengan pendekatan kuantitatif. Dengan tujuan untuk mendapatkan data yang sistematis dengan tepat yang telah ditetapkan lalu menggunakan pendekatan deskriptif dengan tujuan untuk mendeskripsikan objek penelitian ataupun hasil data yang di peroleh dalam penelitian. Dalam penelitian ini data primer yang didapat dari hasil data kuesioner di analisis dengan skala pengukuran. Dalam penelitian ini skala pengukuran yang digunakan adalah skala guttman. Kemudian data jawaban tersebut akan menghasilkan data interval. Data primer yang berupa skala guttman tersebut kemudian di olah dengan metode Univariat Sehingga hasil data mudah untuk peneliti 
deskripsikan. Selanjutnya di analisis dengan deskriptif yang dimaksud dengan analisis deskriptif adalah menggambarkan yang ada guna memperoleh bentuk nyata dari responden, sehingga lebih mudah dimengerti peneliti atau orang lain yang tertarik dengan hasil penelitian yang dilakukan. Tujuan dilakukan analisis deskriptif dengan teknik statistika adalah untuk meringkas data agar menjadi lebih mudah dilihat dan dimengerti

\section{HASIL PENELITIAN}

1) Siswa menerima semua temannya yang berada di lingkungan sekolah dan rumah tanpa membedabedakan agamanya. Perkembangan seorang siswa dalam kehidupan sehari-harinya tidak terlepas kepada siapa teman bermainnya di lingkungan sekitar misalnya tempat tinggal atau rumah dan lingkungan sekolahan yang dimana mereka-mereka ini yang menjadi objek pertumbuhan dari seorang siswa dalam melihat relalitas sosial yang terjadi pada lingkungannya.

Tabel 1

Hasil data Univariat Pernyataan 1

\begin{tabular}{|l|c|c|}
\hline Alternatif Jawaban & Frekuensi & Persentase \\
\hline Tidak Setuju & - & - \\
\hline Setuju & 266 & $100 \%$ \\
\hline
\end{tabular}

Sumber: Hasil Pengolahan SPSS 26 Tahun 2020.

Tabel diatas menunjukan bahwa seluruh siswa menyatakan setuju dengan pernyataan 1 . Berdasarkan observasi siswa memiliki teman-teman yang berbeda agama dengannya di lingkungan sekolah maupun rumah dan mereka saling berteman dan bermain bersama dalam kesempatan waktu yang sama, baik saling mendatangi rumah masing-masing, saling bermain bersama, mengobrol, dan melakukan kegiatan sehari-hari. Hal ini menunjukkan persepsi yang positif bagaimana pada proses persepsi awal siswa melakukan seleksi atas realitas sosial keberagaman agama yang terjadi dengan contoh mereka memilih teman-temannya tidak berlandaskan kesamaan agama.

2) Siswa bersedia menerima pendapat dari semua temannya tanpa membeda-bedakan agamanya. Pendapat merupakan suatu ide atau gagasan yang diberikan oleh orang lain kepada individu untuk mendapatkan solusi untuk individu yang menerimanya atau bahkan solusi untuk bersama. Siswa juga akan mendapatkan sebuah ide atau gagasan yang diberikan oleh teman- temannya pada saat melakukan aktivitas bersama dalam kehidupan sehari-hari tidak terlepas kepada teman-temannya yang berbeda agama.

Tabel 2

Hasil data Univariat Pernyataan 2

\begin{tabular}{|l|c|c|}
\hline Alternatif Jawaban & Frekuensi & Persentase \\
\hline Tidak Setuju & 18 & $6,8 \%$ \\
\hline Setuju & 248 & $93,2 \%$ \\
\hline Total & 266 & $100 \%$ \\
\hline
\end{tabular}

Sumber: Hasil Pengolahan SPSS 26 Tahun 2020.

Tabel diatas menunjukan bahwa Sebagian Besar siswa menyatakan setuju dengan pernyataan 2. Berdasarkan hasil observasi siswa memiliki kelompok diskusi yang terdiri dari berbagai agama di lingkungan sekolahnya hal ini memaknai mereka saling bertukar pikiran dan saling membagi pendapat satu diantara lainnya dalam melaksanakan tugas sekolah yang diberikan oleh gurunya, hal ini juga merupakan suatu proses persepsi yang dilakukan oleh siswa dengan cara berinteraksi saling bertukar pendapat dan saling menghargai pendapat diantara mereka. 
3. Siswa memanggil temannya dengan nama yang paling disukainya meskipun berbeda agama. Pertemanan yang dilakukan siswa antar temannya pasti memiliki ciri khas tertentu dalam kehidupan yang mereka lakukan sebagaimana misal dengan memberikan ciri khas nama-nama tertentu kepada teman-temanya seperti nama gelar, nama marga, atau pun nama yang diberikan dan disepakati bersama teman-temannya atau lain sebagainya.

Tabel 3

Hasil data Univariat Pernyataan 3

\begin{tabular}{|l|c|c|}
\hline Alternatif Jawaban & Frekuensi & Persentase \\
\hline ak Setuju & 34 & $12,8 \%$ \\
\hline uju & 232 & $87,2 \%$ \\
\hline al & 266 & $100 \%$ \\
\hline
\end{tabular}

Sumber: Hasil Pengolahan SPSS 26 Tahun 2020.

Berdasarkan observasi dengan adanya nama-nama gelar atau sebutan yang menarik antara sesama siswa dalam memanggil teman-temanya baik sesame agama dan yang berbeda agama hal ini disebutkan bahwa mereka menjadikan hal ini sebagai bukti bahwa keeratan dan kedekatan mereka dalam berteman. Hal tersebut memberikan sinyal positif kepada keberagaman yang ada karena siswa memiliki persepsi yang positif dengan keberagaman ini, hal ini juga termasuk dalam proses persespi yaitu saling berinteraksi satu sama lainnya.

4) Siswa memaksa teman yang berbeda agama dengannya untuk menghargai apapun yang ia lakukan. Menghargai apapun yang dilakukan orang lain merupakan bentuk dari keberagaman itu sendiri sehingga menghargai apapun yang dilakukan orang lain terlebih jika berbeda agama sangat menjaga harmonisasi dalam kehidupan antar umar beragama.

Tabel 4

\begin{tabular}{|l|c|c|}
\multicolumn{2}{c}{ Hasil data Univariat Pernyataan 4 } \\
\hline Alternatif Jawaban & Frekuensi & Persentase \\
\hline Tidak Setuju & 239 & $89,8 \%$ \\
\hline Setuju & 27 & $10,2 \%$ \\
\hline Total & 266 & $100 \%$ \\
\hline
\end{tabular}

Sumber: Hasil Pengolahan SPSS 26 Tahun 2020

5) Berdasarkan observasi siswa mewujudkannya dalam kelompok belajar tadi bahwa mereka berkumpul untuk saling bertukar pikiran dan mencari solusi bersama bukan untuk saling memaksa pendapat dan kehendaknya. Selanjutnya kebebasan dalam mengutarakan pendapat dan melaksanakan segala aktivitas keagamaan merupakan bagian dari keberagaman sehingga tidak ada paksaan yang dilakukan siswa dalam menjalankanya. Hal ini juga merupakan persepsi yang positif dan tahapan dalam mempengaruhi persepsi sesorang.

6) Siswa berkeyakinan hanya ajaran agamanya saja yang perlu diketahui dan dihargai.

Keyakinan sesorang dalam beragama merupakan suatu prinsip yang dianggap benar tanpa ada keraguan lagi dan praktik agama merupakan cara mereka yang beragama dalam melakukan hubungan vertical antar umat manusia dan hubungan horizontal dengan tuhannya.

Tabel 5

Hasil data Univariat Pernyataan 5

\begin{tabular}{|l|c|c|c|}
\hline Alternatif Jawaban & & Frekuensi & Persentase \\
\hline Tidak Setuju & & 190 & $71,4 \%$ \\
\hline Setuju & & 76 & $28,6 \%$ \\
\hline Total & & 266 & $100 \%$ \\
\hline
\end{tabular}

Sumber: Hasil Pengolahan SPSS 26 Tahun 2020 
6) Keyakinan seseorang yang ia yakini dari lahir sangat sulit untuk kita ubah, namun saling menghargai agama yang ada menjadi suatu wujud dalam kehidupan beragama yang baik terdapat peristiwa di mana siswa saling membantu dalam kegiatan wejangan jumat pagi di sekolahnya. Dengan dilaksanakan kegiatan ini yang secara garis besar merupakan kegiatan bagi umat islam namun jika sudah waktunya kelas mereka mendapat giliran untuk menjadi panitia wejangan jumat pagi, bagi siswa yang bukan agama islam tetap ikut bersama-sama membantu mensukseskan kegiatan ini dengan membantu membawa alat-alat kegiatan dan bahkan memberikan ide dalam pertunjukan.

7) Siswa keberatan apabila ada yang mendirikan tempat ibadah agama lain di lingkungan rumah. Rumah ibadah merupakan tempat bagi umat beragama melaksanakan kegiatan keagamaanya dan menjadi tempat berkumpul umat beragama dalam melakukan segala aktivitas yang berhubungan dengan kehidupan beragamanya.

Tabel 6

Hasil data Univariat Pernyataan 6

\begin{tabular}{|l|c|c|c|}
\hline Alternatif Jawaban & & Frekuensi & Persentase \\
\hline Tidak Setuju & & 260 & $97,7 \%$ \\
\hline Setuju & & 6 & $2,3 \%$ \\
\hline Total & & 266 & $100 \%$ \\
\hline
\end{tabular}

Sumber: Hasil Pengolahan SPSS 26 Tahun 2020

Tabel diatas menunjukan bahwa sebagian kecil siswa setuju dengan pernyataan 6 . Berdasarkan observasi terdapat siswa yang tempat tinggalnya berada di lingkungan mayoritas agama yang berbeda dengan agamanya yang menjadi minoritas dan di sana terdapat rumah ibadah dari masyarakat yang beragama mayoritas tersebut.

8) Dengan teman yang berbeda agama, siswa selalu memberi kesempatan untuk beribadah sesuai ajaran yang diyakininya. Beribadah merupakan suatu kegiatan yang diyakani seorang individu yang beragama dimana segala aktivitasnya akan mendapatkan pahala atau imbalan dari tuhannya secara langsung maupun tidak langsung sehingga perlu adanya kebebasan seorang yang beragama dalam melaksanakannya.

Tabel 7

Hasil data Univariat Pernyataan 7

\begin{tabular}{|l|c|c|}
\hline Alternatif Jawaban & Frekuensi & Persentase \\
\hline Tidak Setuju & 3 & $1,1 \%$ \\
\hline Setuju & 263 & $98,9 \%$ \\
\hline Total & 266 & $100 \%$ \\
\hline
\end{tabular}

Sumber: Hasil Pengolahan SPSS 26 Tahun 2020

\section{PEMBAHASAN}

Berikut Analisis Sosiologi dari Persepsi Siswa Terhadap Keberagaman Agama Di Kota Tanjungpinang (Studi Kasus Pada siswa SMA/SMK/MA Di Kota Tanjungpinang). Setiap penganut agama mempercayai bahwa agama yang dianutnya adalah agama yang paling benar, dan mereka berusaha menyebarluaskan kepercayaannya sebagai sebuah kebenaran, oleh karena itu terkadang individu yang mendapatkan pesan kepercayaan itu kadang-kandang menimbulkan berbagai bentuk ketegangan di tengah-tengah masyarakat yang pluralistik seperti di kota Tanjungpinang. Hal ini menandakan bahwa agama termasuk kedalam konstruksi sosial yang harus dipelihara dan dilestarikan.

Selanjutnya agama dalam pandangan sosiologi merupakan pandangan hidup yang harus 
diterapkan dalam kehidupan masyarakat. Keduanya mempunyai hubungan saling mempengaruhi dan saling bergantung antara satu bagian dengan bagian lainnya. Yang artinya bahwa agama menjadi salah satu acuan pedoman hidup bagi masyarakat untuk menjalankan kehidupannya terlebih khusus kepada masyarakat kota Tanjungpinang yang memiliki berbagai budaya kedaerahanya yang sama-sama memiliki tata cara adat istiadat untuk mengatur berinteraksi, bertindak, dan dalam melaksanakan kegiatan kehidupannya sehari-hari di dalam masyarakat.

Di dalam kehidupan masyarakat Kota Tanjungpinang juga terdapat berbagai organisasi sosial keagamaan yang merupakan bagian dari unsur kebudayaan dan juga menunjukan sebuah bentuk keberagaman agama yang masih bebas dan terjaga hingga saat ini seperti, muhammadiyah, Nahdahtul Ulama, Persatuan Umat Kristen Indonesia,persatuan umaat Buddha Indonesia, persatuan umat hindu Indonesia, organisasi gerja khatolik, dan persatuan umat kong hu chu Indonesia. Selain itu institusi sosial lainnya yang masih berdiri tegak dan bebas aman terjaga untuk melaksanakan kegiatannya juga dilihat dari segi pendidikan di kota Tanjupinang masih terdapat sekolah yang bersifat keagamaan seperti, SMA Muhammadiyah Tanjungpinang, SMA Santa Maria, SMA Maitreyawira, dan sekolah dasar maupun sekolah menengah pertama yang bersifat sekolah keagamaan tertentu yang dimana dari dahulu hingga sekarang sekolah-sekolah ini legal dan berfungsi dengan baik. Selanjutnya dari tempat ibadah yang ada di kota tanjungpinang seperti masjid, gereja, vihara, dan tempat ibadah lainnya masih berdiri tegak dan menjalankan fungsi sebagai tempat untuk masyarakat beribadah.

Karakteristik perspektif sosiologi memiliki dua bentuk utama dalam melihat agama. Pertama, bersifat empiris, Dalam sosiologi tentang agama berupaya mendasarkan interpretasi-interpretasinya pada data. Penjelasan mereka tentang kenyataan sosial didasarkan pada pengalaman-pengalaman kongkrit. Kedua, bersifat objektif bahwa interpertaasi-interpretasi mereka tentang agama berdasarkan data yang ada (das sein) dan bukan menurut apa yang seharusnya (das sollen). Berangkat dari dasar sosiologi melihat agama ini berkembang kepada persepsi individu melihat sesuatu yang ada dan dalam penelitian ini yaitu siswa melihat keberagaman agama yang ada di Kota Tanjungpinang. Persepsi yang timbul didalam diri siswa untuk melihat keberagaman agama yang ada ia dapatkan dari berbagai informasi yang ada di kota Tanjungpinang dengan maraknya baliho atau spanduk ucapan selamat atau turut bersuka cita atau berduka cita kepada mereka yang berbeda agama, di lingkungan tempat tinggalnya siswa sering bermain pada temannya yang berbeda agama dan pada saat hari besar keagamaan mereka saling mengucapkan dan dating kerumah temannya yang sedang merayakan, di lingkungan sekolah mereka berinteraksi dan melihat tindakan dari teman-temanya yang berbeda agama dengannya terus menerus namun dengan keadaan pandemi seperti ini tidak melunturkan mereka untuk tetap berkomunikasi dengan teman-temannya lewat media-media komunikasi.

Hal ini sejalan dengan pendapatnya bahwa Persepsi merupakan suatu proses yang dipelajari melalui interaksi dengan lingkungan sekitar. Persepsi seseorang timbul sejak kecil melalui interaksi dengan manusia lain. Menurut Soerjono Soekanto dalam Burhan Bungin (2009:55) bentuk umum proses sosial adalah interaksi sosial, sedangkan bentuk khususnya adalah aktivitas-aktivitas sosial. Interaksi sosial merupakan hubungan sosial yang dinamis menyangkut hubungan antara orang perorangan, antara kelompok manusia, maupun antara orang perorangan dengan kelompok manusia. Siswa secara individu melakukan hubungan sosial dengan temanya yang berbeda agama dan sekolah secara kelompok memberikan tempat atau wadah terjadinya hubungan sosial dari berbagai individu yang masuk dan berada di dalam sekolah untuk saling berhubungan dan berinteraksi satu sama lainnya hal ini lah yang membentuk persepsi siswa terhadapat keberagaman agama yang ada di Kota Tanjungpinang.

\section{KESIMPULAN}

Persepsi yang timbul dalam diri siswa mengenai keberagaman agama di kota Tanjungpinang ini karena mereka melakukan interaksi, melakukan tindakan, dan melihat realitas sosial yang terjadi di kota 
Tanjungpinang dengan masyarakatnya yang memiliki keberagaman agama yang dilihat dari kegiatan ibadah keagamaan, organisasi keagamaan, dan tempat ibadah agama yang beragaman di kota Tanjungpinang. Berdasarkan data di atas dapat ditarik kesimpulan bahwa apa yang terjadi di masyarakat kota Tanjungpinang dengan keberagaman agama akan membentuk persepsi dan pandangan pada siswa tentang realitas sosial ini dengan pola interaksi, tingkah laku, tindakan, dan kegiatan-kegiatan ibadah masyarakat kota Tanjungpinang yang dari dahulu hingga sekarang masih bisa melakukan dengan bebas,aman, dan nyaman sehingga hal-hal ini menjadikan keberagaman agama yang ada di kota Tanjungpinang masih terjaga hingga saat ini. Yang dimana pada siswa mereka melihat kegiatan ini tidak terjadi di lingkungan umum sekitar rumahnya namun juga terjadi di lingkungan sekolahnya yang dimana banyak terdapat teman-teman satu sekolah mereka yang juga memiliki keberagaman agama yang beragaman. Sehingga mereka dapat melihat miniatur keberagaman agama masyarakat kota Tanjungpinang di lingkungan sekolahnya, yang dimana mereka bisa berinteraksi dengan temannya yang berbeda agama, saling tukar pendapat dengan temannya yang berbeda agama, saling bermain bersama, saling tolong-menolong jika ada temannya yang membutuhkan, dan melihat kegiatan dan ritual keagamaan yang dilakukan temannya yang berbeda agama dengannya.

\section{DAFTAR PUSTAKA}

Anggraeni, Dewi \& Suhartinah, Siti. 2018. Jurnal Studi Al-Qur'an Membangun Tradisi Berfikir Qur'an "Toleransi Antar Umat Beragama Perspektif KH. Ali Mustafa Yaqub". Vol. 14, No. 1.

Charles R. Ngangi. 2011. Jurnal ASE "Konstruksi Sosial Dalam Realitas Sosial". Volume 7 Nomor 2, Mei : $1-4$.

Damsar. 2015. Pengantar Teori Sosiologi. Jakarta: PT. Kharisma Putra Utama. Hanurawan, Fattah. 2010. Psikologi Sosial (PT Remaja Rosdakarya).

Indah Rahayu. 2018 Jurnal Aqidah-Ta.UIN Alauddin Makassar. "Persepsi Siswa SMP Unismuh Makassar Terhadap Toleransi Antarumat Beragama. Vol. IV No. 1.

Kahmad, Dadang. 2009. Sosiologi Agama. Bandung: PT. Remaja Rosdakarya.

Michael Keene. 2012. Agama-Agama Dunia . (Yogyakarta: Kanisius)

Nurdin, Ali, dkk. 2013. Pengantar Ilmu Komunikasi, Surabaya: IAIN Press, Nia Kurnia. 2020. Skripsi IAIN Purwokerto, "Konstruksi Sosial Toleransi Antar Umat Beragama di Desa Grujugan Kecamatan Petanahan Kabupaten Kebumen".

Pitus A Partato, M Dahlan Al Barry. 2001. Kamus Ilmiah popular . (Surabaya : Arkola)

Setiadi, Elly M. 2020. Pengantar Ringkas Sosiologi: "Pemahaman Fakta dan Gejala Permasalahan Sosial". Jakarta: Kencana.

Sugiyono. 2016. Metode Penelitian Kuantitatif, Kualitatif, dan R\&D. Bandung: Alfabeta.

Wibowo. 2014. Perilaku Dalam Organisasi. (Jakarta : Raja Grafindo Persada,) 